\title{
CONJUGATED PLATINUM-POLY-YNES WITH EXTENDED ARYLENE ETHYNYLENES
}

\author{
MASNUN NAHER, SHAWON SHAHRIAR MEHDI, MD. KAUSAR AHMED, \\ MD. MOSTAFIJUR RAHMAN, MOHAMMAD MIZANUR RAHMAN KHAN AND \\ MUHAMMAD YOUNUS* \\ Department of Chemistry, Shahjalal University of Science and Technology, Sylhet-3114, \\ Bangladesh
}

\begin{abstract}
The platinum-poly-yne polymers poly[trans-bis(tri-n-butylphosphine) platinum-poly $\left(4,4^{\prime}\right.$ diethynylenearylene)] (arylene $=$ biphenylene $\mathbf{3}$ and anthracene 4) were synthesized by the condensation reaction between poly(diethynylenearylene) (arylene = biphenylene $\mathbf{1}$ and anthracene 2) and trans- $\left[\left(\mathrm{P}^{\mathrm{n}} \mathrm{Bu}_{3}\right)_{2} \mathrm{PtCl}_{2}\right]$ in diisopropyl amine and dichloromethane under nitrogen atmosphere in the presence of $\mathrm{CuI}$ catalyst. The newly synthesized platinum containing poly-yne polymers exhibit good solubility in common organic solvents. These metal linked polymers were characterized by IR, ${ }^{1} \mathrm{H}$ NMR and ${ }^{31} \mathrm{P}$ NMR spectroscopy.
\end{abstract}

Key words: Platinum-poly-yne polymer, Conjugated organic polymer, Hay's oxidative coupling, Condensation

\section{INTRODUCTION}

Metal containing poly-ynes are of current research interest due to the potential for combining the characteristics of transition metals and conjugated organic polymers within one material (Molapo et al. 2012, Cyr et al. 2005). The conjugated o-bonded acetylide complexes and their metallated derivatives with a wide domain of intriguing properties are very useful for the development of optoelectronic devices, such as, organic light emitting diodes (OLEDs), photovoltaic cell, field effect transistors (FET), sensor and non linear optical materials (Long et al. 2003). Owing to their rigid rod linear structure, they also behave as liquid crystals (Amato et al. 2004). These properties depend on the fragments of the poly-ynes: (a) metals, (b) auxiliary phosphine ligand and (c) $\sigma$-bonded acetylide ligands (Long et al. 2005). The structure of organometallic polymers (Fig. 1) can be modified by changing the metal, the auxiliary ligands, or the spacers (Younus et al. 1998).

Organometallic polymers containing Group 8 - 10 metals in the backbone are highly soluble in common organic solvents and these polymers are stable in air. Polymer

\footnotetext{
* Corresponding author: <myounus-che@ sust.edu>
} 
stability is one of the most important criteria for their application as conducting polymers in various practical devices (Alsalhi et al. 2011). Due to the presence of $d$-orbitals in the metal, conjugation in these polymers can be maintained through the metal centre. Some metal-poly-yne polymers were designed by using the concept of alternating donor and acceptor units (Younus et al. 1998).

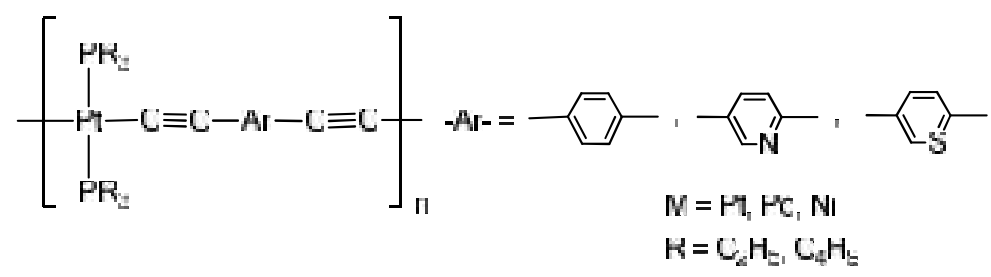

Fig. 1. Structure of organometallic polymers.

In recent works, the authors reported the synthesis of platinum-poly-ynes with phosphines other than tri-n-butylphosphine. These include platinum ethynyl conplexes with 1,2-bis(diphenylphosphinoethane), dppe, - cis-[Pt(dppe) $\left(-\mathrm{C} \equiv \mathrm{C}-\mathrm{C}_{6} \mathrm{H}_{4}-p-\mathrm{C} \equiv \mathrm{CH}\right)_{2}$, cis$\left[\mathrm{Pt}(\mathrm{dppe})\left(-\mathrm{C} \equiv \mathrm{C}-\mathrm{C}_{6} \mathrm{H}_{4}-p-\mathrm{C}_{6} \mathrm{H}_{4}-p-\mathrm{C} \equiv \mathrm{CH}\right)_{2}\right.$ cis-[Pt(dppe) $\left(-\mathrm{C} \equiv \mathrm{C}-\mathrm{C}_{6} \mathrm{H}_{4}-p-\mathrm{CH}_{3}\right)_{2}$ (Saha et al. 2005) and tri-tolylphosphines containing platinum poly-yne polymers i.e. [-Pt(p-tolyl3P $\left.)_{2} \mathrm{C} \equiv \mathrm{C}-\mathrm{R}-\mathrm{C} \equiv \mathrm{C}-\right] \mathrm{n}, \quad(\mathrm{R}=$ biphenyl and 2,5-dioctyloxybenzene) (Sina et al. 2014). The synthesis of platinum end-capped poly(aryleneethylene)s - $\left[\mathrm{Ph}\left(\mathrm{P}^{\mathrm{n}} \mathrm{Bu}_{3}\right)_{2} \mathrm{Pt}-\right.$ $\mathrm{C} \equiv \mathrm{C}-(\mathrm{Ar}-\mathrm{C} \equiv \mathrm{C}-\mathrm{C} \equiv \mathrm{C})_{\mathrm{n}}-\mathrm{Pt}\left(\left(\mathrm{P}^{\mathrm{n}} \mathrm{Bu}_{3}\right)_{2} \mathrm{Ph}\right]\left\{\mathrm{Ar}=\mathrm{C}_{5} \mathrm{H}_{5} \mathrm{~N}, \mathrm{C}_{6} \mathrm{H}_{6}, \mathrm{C}_{6} \mathrm{H}_{4}\left(\mathrm{CH}_{3}\right)_{2}, \mathrm{C}_{6} \mathrm{H}_{4}-\mathrm{C}_{6} \mathrm{H}_{4}\right\}$ has also been reported (Hossain et al. 2011).

The authors report the synthesis of a series of extended poly-ynes where platinum is in the main chain. The molecular structure of newly synthesized metal poly-ynes is shown in Fig. 2.

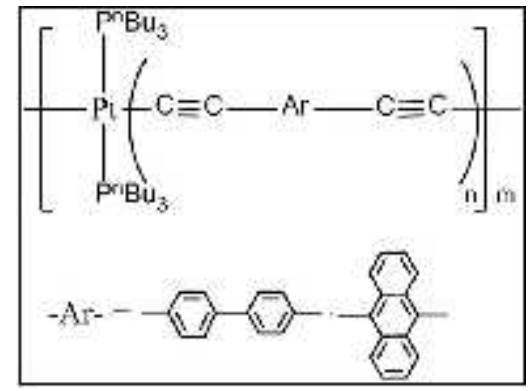

Fig. 2. Molecular structure of poly[trans-bis(tri-n-butylphosphine) platinum-poly (4,4’- diethynylenearylene)].

\section{MATERIALS AND METHODS}

Trans- $\left[\left(\mathrm{P}^{\mathrm{n}} \mathrm{Bu}_{3}\right)_{2} \mathrm{PtCl}_{2}\right]$, Copper(I)iodide, copper(I)chloride, and tetramethylethylenediamine (TMEDA) were purchased from Aldrich, Germany. The starting materials 4,4'- 
diethynylphenyl, 4,4'-diethynylbiphenyl (Xu et al. 2012) and 9, 10-diethynyleneanthracene (Baier et al. 2009) were prepared by the methods previously reported. All the solvents dichloromethane $\left(\mathrm{CH}_{2} \mathrm{Cl}_{2}\right)$, diisopropylamine $\left({ }^{i} \mathrm{Pr}_{2} \mathrm{NH}\right)$ and tetrahydrofuran (THF) were purchased from Merck, Germany. Alumina for column chromatography (Aluminium oxide 90 active, neutral, 70-230 mesh ASTM, particle size 0.063 - 0.02120), $\mathrm{k}$ and thin layer chromatography (TLC) plates were also purchased from Merck, Germany.

The Infrared spectra of all the compounds were recorded on $\mathrm{KBr}$ pellets with a SHIMADZU IR spectrometer (Prestige 21). Standard ${ }^{1} \mathrm{H}$ NMR and ${ }^{31} \mathrm{P}$ NMR spectra were recorded on a BRUKER 400M Hz NMR spectrometer, at BCSIR, Dhaka, Bangladesh.

Synthesis of $m L \quad$ (4,4'-diethynylenebyphenylene) 1: Poly(4,4'diethynylenebiphenylene) 1 were prepared by the adaption of the synthetic route reported by Kloppenburg et al. 1999. Freshly distilled and dried THF $(20 \mathrm{~mL})$ were added into $\mathrm{CuCl}(0.010 \mathrm{~g})$ and TMEDA (N, N, N', $\mathrm{N}^{\prime}$-tetramethylethylenediamine) $(0.015 \mathrm{~g})$, and the reaction mixture was bubbled by oxygen gas for 10 minutes. A solution of 4,4'diethynylbiphenyl monomer $(0.050 \mathrm{~g}, 0.247 \mathrm{mmol})$ in $5 \mathrm{~mL}$ THF was then added to the reaction, and it was stirred for 24 hours at room temperature under oxygen atmosphere. A pale yellow colored precipitate was formed in the flask. The crude product was purified by washing it with $\mathrm{MeOH}-\mathrm{HCl}$, then with methanol, and dried under vacuum. Yield $95 \%$ $(0.047 \mathrm{~g}) . \mathrm{IR}\left(\mathrm{cm}^{-1}\right): v(\mathrm{C} \equiv \mathrm{C}), 2106 ; v$ (aromatic $\left.\mathrm{C}=\mathrm{C}\right), 1602$ and 1489; $v$ (aromatic $\left.\mathrm{C}-\mathrm{H}\right)$, 3066; v ( 三C-H), 3286.

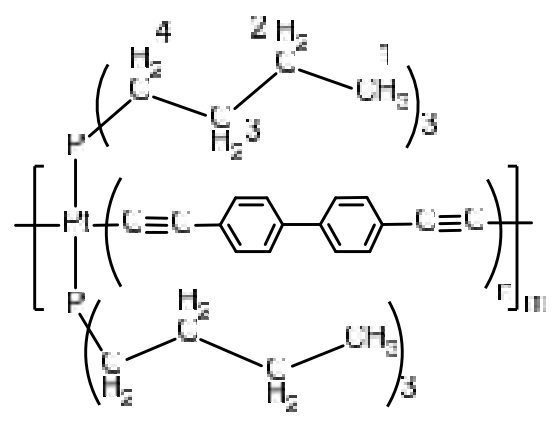

3

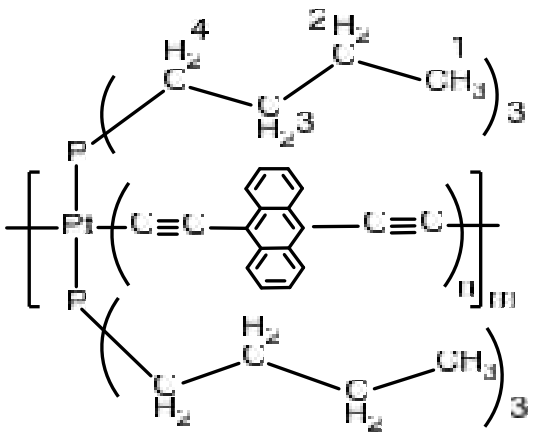

4

Fig. 3. Structure of metal-poly-yne polymers 3 and 4 .

Synthesis of poly(9, 10-diethynyleneanthracene) 2: The procedure for $\mathbf{1}$ was followed, but using 9,10-diethynyleneanthracene $(0.01 \mathrm{~g})$ instead of 4,4'diethynylenebiphenylene to give $\operatorname{Poly}(9,10$-diethynyleneanthracene). $75 \%$ yield $(0.075$ 
g). IR $\left(\mathrm{cm}^{-1}\right): v(\mathrm{C} \equiv \mathrm{C}), 2096 ; v$ (aromatic $\left.\mathrm{C}=\mathrm{C}\right), 1670$ and 1489; $v$ (aromatic $\left.\mathrm{C}-\mathrm{H}\right), 3059$; $v($ C $-\mathrm{H}), 3278$.

Synthesis of poly[trans-bis(tri-n-butylphosphine)platinum poly (4, 4'diethynylenebiphenylene) 3: To a mixture of freshly distilled, dried and degassed diisopropylamine $(10 \mathrm{~mL})$ and dichloromethane $(20 \mathrm{~mL})$ trans $-\left[\left(\mathrm{P}^{\mathrm{n}} \mathrm{Bu}_{3}\right)_{2} \mathrm{PtCl}_{2}\right](0.0186 \mathrm{~g})$, poly $\left(4,4^{\prime}-\right.$ diethynylenebiphenylene) $\mathbf{1}$ (0.05 g) and copper(I) iodide (10 mg) were added and it was stirred at $68^{\circ} \mathrm{C}$ temperature for 48 hours under nitrogen atmosphere. Then the solvents were removed under reduced pressure, and the crude polymer was extracted with dichloromethane and dried under vacuum. The product was purified column chromatography over alumina using dichlromethane and methanol $(30: 1)$ as eluent. Yield $75 \%(0.024 \mathrm{~g}) . \mathrm{IR}\left(\mathrm{cm}^{-1}\right): v(\mathrm{C} \equiv \mathrm{C}), 2096 ; v$ (aromatic $\left.\mathrm{C}=\mathrm{C}\right), 1541$ and 1486; $v$ (aromatic $\mathrm{C}-\mathrm{H}), 3029 ; v$ (methyl C-H), 2910; $v$ (Pt-C) 668. ${ }^{1} \mathrm{H}$ NMR $\left(\mathrm{CDCl}_{3}, \delta \mathrm{ppm}\right): 0.89$ (m, $-\mathrm{H}_{3}{ }^{1}$, ${ }^{\mathrm{n}} \mathrm{Bu}$ ), 1.18 (m, $-\mathrm{CH}_{2}{ }^{2} \mathrm{CH}_{3},{ }^{\mathrm{n}} \mathrm{Bu}$ ), 1.41 (m, $\left.-\mathrm{CH}_{2}{ }^{3} \mathrm{CH}_{2} \mathrm{CH}_{3},{ }^{\mathrm{n}} \mathrm{Bu}\right), 2.16$ (m, $-\mathrm{CH}_{2}{ }^{4} \mathrm{CH}_{2} \mathrm{CH}_{2} \mathrm{CH}_{3}$, ${ }^{\mathrm{n}} \mathrm{Bu}$ ) multiplet at $\delta 7.46-7.56\left(\mathrm{~m}\right.$, benzene ring). ${ }^{31} \mathrm{P}$ NMR: one singlet at 4.67 with two satellite at $\delta 11.96$ and $-2.58\left(J_{P t-P}\right)=2355 \mathrm{~Hz}$.

Synthesis of poly[trans-bis(tri-n-butylphosphine) platinum poly(9,10-diethynyleneanthracene] 4: The procedure for 3 was followed but using poly $(9,10$-diethynyleneanthracene) $\mathbf{2}(0.05 \mathrm{~g})$ instead of poly $\left(4,4^{\prime}\right.$-diethynylenebiphenylene) $\mathbf{1}$ to give poly[transbis (tri-n-butylphosphine) platinum poly(9,10-diethynyleneanthracene] 4. Yield 69\% $(0.047 \mathrm{~g})$. IR $\left(\mathrm{cm}^{-1}\right): v(\mathrm{C} \equiv \mathrm{C}), 2085 ; v($ aromatic $\mathrm{C}=\mathrm{C}), 1465 ; v$ (aromatic $\left.\mathrm{C}-\mathrm{H}\right), 3029 ; v$ (methyl C-H), 2958; v (Pt-C) 668. ${ }^{1} \mathrm{H} \mathrm{NMR}\left(\mathrm{CDCl}_{3}, \delta \mathrm{ppm}\right):{ }^{1} \mathrm{H} \mathrm{NMR}\left(\mathrm{CDCl}_{3}, \delta \mathrm{ppm}\right)$ : 0.88 (m, $\left.-\mathrm{CH}_{3}{ }^{1},{ }^{\mathrm{n}} \mathrm{Bu}\right), 1.25$ (m, $\left.-\mathrm{CH}_{2}{ }^{2} \mathrm{CH}_{3},{ }^{\mathrm{n}} \mathrm{Bu}\right), 1.53$ (m, - $\left.\mathrm{CH}_{2}{ }^{3} \mathrm{CH}_{2} \mathrm{CH}_{3},{ }^{\mathrm{n}} \mathrm{Bu}\right), 2.17$ (m, $\mathrm{CH}_{2}{ }^{4} \mathrm{CH}_{2} \mathrm{CH}_{2} \mathrm{CH}_{3},{ }^{n} \mathrm{Bu}$ ) multiplet at $\delta$ 7.52-8.76 (m, benzene ring). ${ }^{31} \mathrm{P}$ NMR: two singlet at $\delta 2.23$ with satellites 9.13 and -4.81 and at $\delta-6.69$ with satellites 0.25 and -13.63 .

\section{RESULTS AND DISCUSSION}

The organic polymers (1 and 2 ) were synthesized by Hay's oxidative coupling reactions which were reported by Hossain et al. 2011. The metal-poly-yne polymers 3 was synthesized (Scheme 1) by the condensation reaction between trans- $\left[\left(\mathrm{P}^{\mathrm{n}} \mathrm{Bu}_{3}\right)_{2} \mathrm{PtCl}_{2}\right]$ and organic polymers $\mathbf{1}$, in diisopropylamine and dichloromethane $(1: 2)$ using $\mathrm{CuI}$ as a catalyst. Poly-yne 4 was formed similarly.

The insoluble nature of the conjugated organic polymers $\mathbf{1}$ and $\mathbf{2}$ limits their characterization by standard spectroscopic techniques (Hattori et al. 1997). Present authors introduced platinum metal in the polymeric chain to increase its solubility and to diversify practical applications. These metal poly-yne polymers were purified by column chromatography, and characterised by IR, ${ }^{1} \mathrm{H}$ NMR and ${ }^{31} \mathrm{P}$ NMR spectroscopy. All these metal-poly-yne polymers $\mathbf{3}$ and $\mathbf{4}$ were pale yellow colored and obtained in high 
percentage (3 - 75, 4 - 69) of yield. As expected the resulting metal poly-yne polymers 3 and 4 were highly soluble in common organic solvent including $\mathrm{CH}_{2} \mathrm{Cl}_{2}$ and $\mathrm{CHCl}_{3}$.

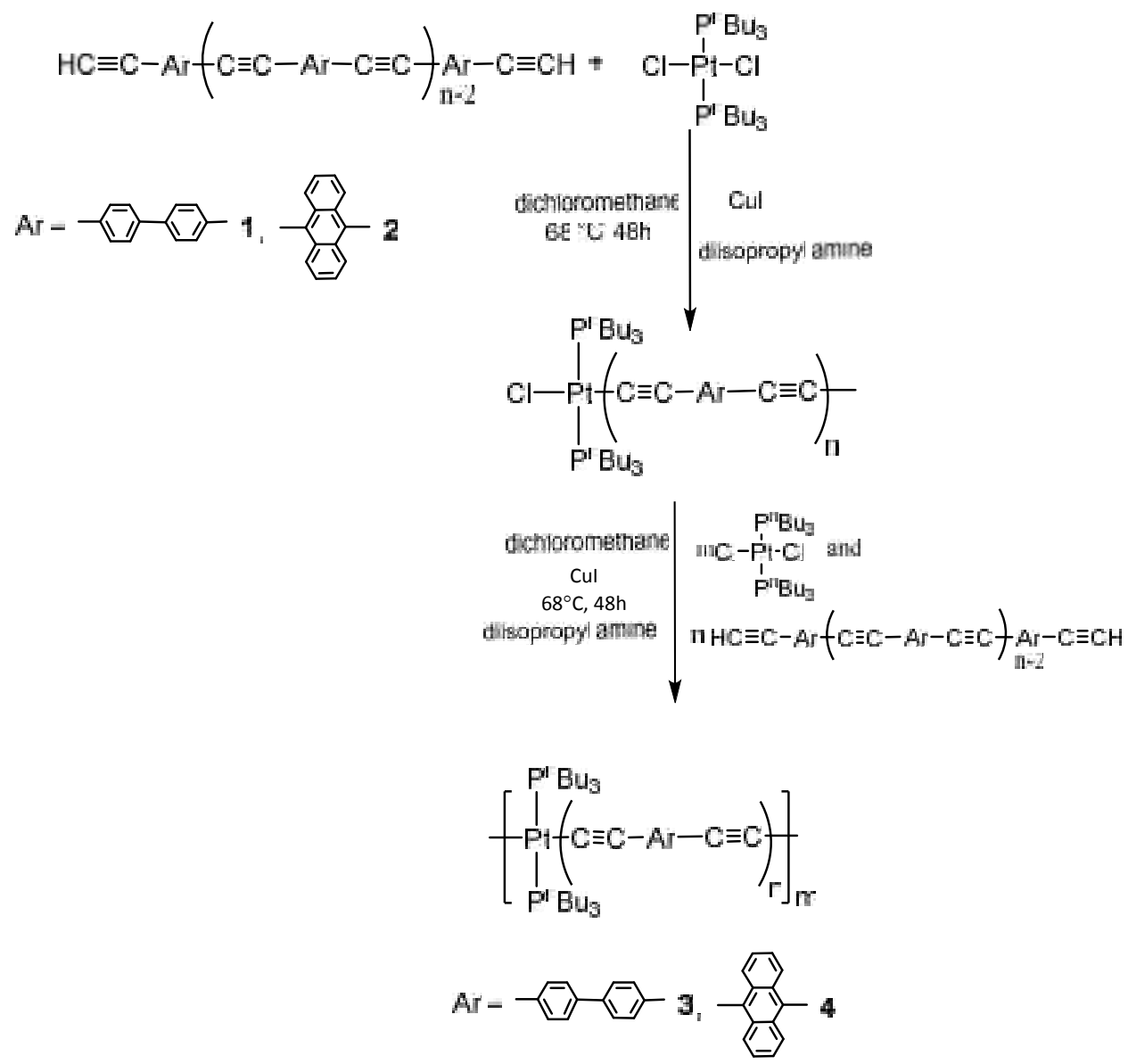

Scheme 1. Synthesis of poly[trans-bis(tri-n-butylphosphine) platinum-poly (4,4'diethynylenearylene)].

In IR spectra, the $v(C \equiv C)$ stretching frequency is diagnostic of the characterization of metal poly-yne polymers, and useful in following the course of reaction. IR spectra of organic polymers 1 and 2 displayed a peak at 3286 and $3278 \mathrm{~cm}^{-1}$ due to the presence of terminal acetylenic hydrogen ( $\equiv \mathrm{C}-\mathrm{H}$ str.) group, and the bands at 2096 and $2094 \mathrm{~cm}^{-1}$ for the ( $\mathrm{C} \equiv \mathrm{C}$ str.). But metal poly-yne polymers $\mathbf{3}$ and $\mathbf{4}$ showed no peak in the range 3200 $3300 \mathrm{~cm}^{-1}$ terminal acetylenic hydrogen ( $\equiv \mathrm{C}-\mathrm{H}$ str.) indicating the formation of Pt-C $\equiv \mathrm{C}$ bond. After metal incorporation the $\mathrm{C} \equiv \mathrm{C}$ bond stretching frequency is shifted from 2106 to $2096 \mathrm{~cm}^{-1}$ for 3 (Fig. 4) and 2094 to $2085 \mathrm{~cm}^{-1}$ for 4 which is the characteristics of $\mathrm{Pt}(\mathrm{II})$ - poly-yne polymers. This may be attributed to either (i) the metal-to-alkyne $\pi$ backbonding or (ii) the $\mathrm{M}^{\delta+}{ }_{-} \mathrm{C}^{\delta-}$ bond polarity (Lewis et al. 1997). 


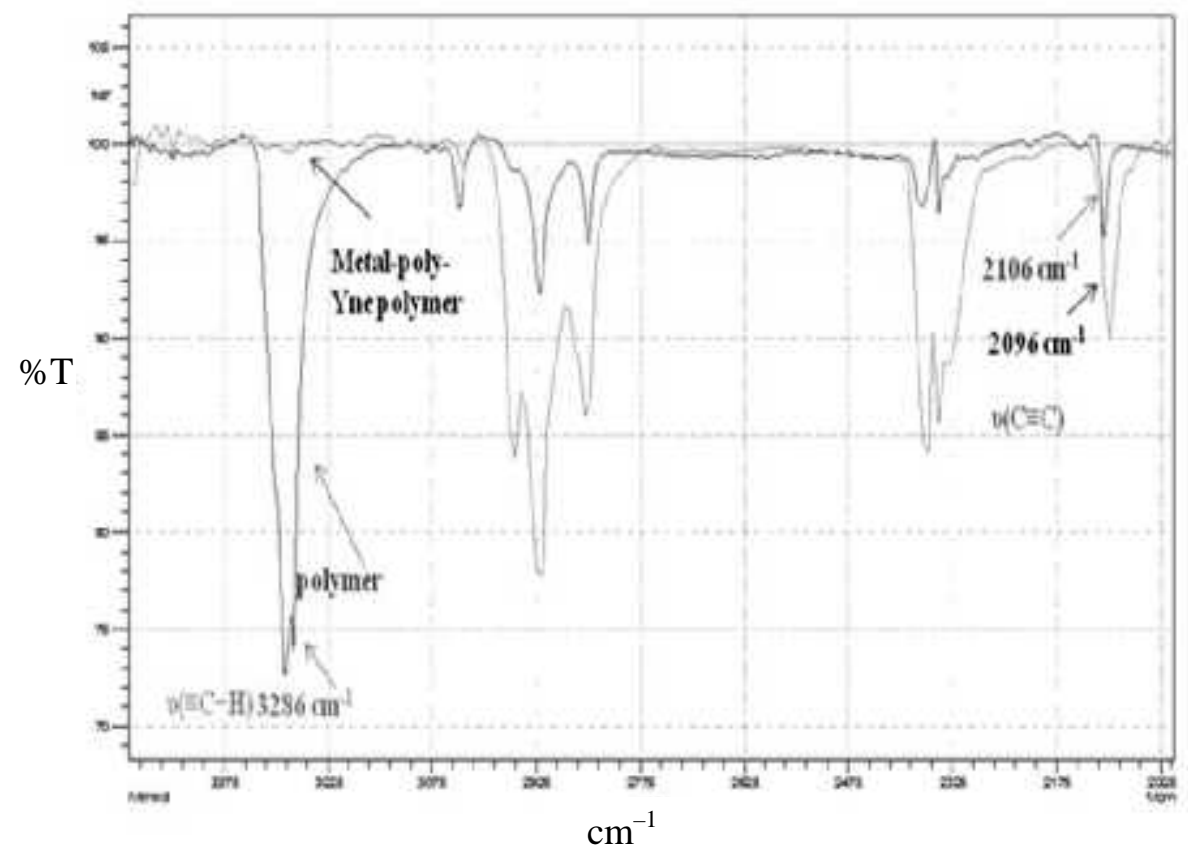

Fig. 4. Comparison IR (KBr) spectra of poly-yne $\mathbf{1}$ and $\mathbf{3 .}$

${ }^{1} \mathrm{H}$ NMR spectrum of polymer 3 (Fig. 3) displayed multiplet at $\delta 0.89,0.94,1.18$, and 1.41 due to the $-\mathrm{CH}_{3}{ }^{1},-\mathrm{CH}_{2}{ }^{2} \mathrm{CH}_{3},-\mathrm{CH}_{2}{ }^{3} \mathrm{CH}_{2} \mathrm{CH}_{3},-\mathrm{CH}_{2}{ }^{4} \mathrm{CH}_{2} \mathrm{CH}_{2} \mathrm{CH}_{3}$ proton resonances of n-butyl and multiplet at $\delta 7.46-7.56$ indicating the proton in the benzene ring. Polymer 4 (Fig. 3) displayed similar ${ }^{1} \mathrm{H}$ NMR signals in the expected region. Sharp signals were not observed due to the oligomeric mixture present in poly-ynes (Hossain $e t$ al. 2011).

For all the Pt(II) poly-ynes, the ${ }^{31} \mathrm{P}$ NMR spectra contained signals with the expected satellites due to the coupling of ${ }^{31} \mathrm{P}$ nuclei with the ${ }^{195} \mathrm{Pt}$. In the ${ }^{31} \mathrm{P}$ NMR spectrum of polymer 3 , a singlet at 4.67 and two satellites at $\delta 11.96$ and -2.58 were displayed with coupling constant of $J_{P t-P}=2355 \mathrm{~Hz}$. This coupling constant value is consistent with a trans -square planar complex, and reflect the greater trans influence of the alkynyl ligands compared to the chloride. (Saha et al. 2005). Polymer 4 displayed one singlet at $\delta$ 2.23 with satellites 0.25 and -13.63 . In addition, signals at $2.23,9.13$, and 4.81 of 4 indicate different molecular weight oligomers with high polydiversity. Another metal poly-yne polymer was synthesized using poly(4,4'diethynylenephenylene) polymer. The ${ }^{31} \mathrm{P}$ NMR spectrum of polymer poly[trans-bis(tri-n-butylphosphine) platinum poly (4,4'diethynylenephenylene)] showed signals at 7.84, 4.74, 0.52 and $-11.23 \mathrm{ppm}$, but no satellites were observed. This indicates depolymerization of the $\mathrm{Pt}(\mathrm{II})$ poly-ynes in $\mathrm{CDCl}_{3}$ solvent. 
Condensation reaction is a very effective process for the synthesis of metal-poly-yne polymers. Though conjugated organic polymers $\mathbf{1}$ and $\mathbf{2}$ are insoluble in common organic solvents, but the metal-poly-yne polymers $\mathbf{3}$ and $\mathbf{4}$ exhibit good solubility. The metalpoly-yne polymers poly[trans-bis(tri-n-butyl phosphine)platinum-poly(4,4'diethynylenebiphenylene)] $\mathbf{3}$ and Poly[trans-bis (tri-n-butylphosphine) platinumpoly (9,10-diethynyleneanthracene] 4 were synthesized by the condensation reaction between poly(diethynylenearylene) $\{$ arylene $=$ biphenylene $\mathbf{1}$ and anthracene 2$\}$ and trans$\left[\left(\mathrm{P}^{\mathrm{n}} \mathrm{Bu}_{3}\right)_{2} \mathrm{PtCl}_{2}\right]$ in diisopropyl amine and dichloromethene under nitrogen atmosphere in the presence of $\mathrm{CuI}$ catalyst. These metal poly-yne polymers were purified by column chromatography, and characterised by IR, ${ }^{1} \mathrm{H}$ NMR and ${ }^{31} \mathrm{P}$ NMR spectroscopy.

\section{ACKNOWLEDGEMENTS}

The authors would like to thank the Higher Education Quality Enhancement Project (HEQEP) of Bangladesh University Grants Commission for financial support.

\section{REFERENCES}

Alsalhi, M. S., J. Alam, L. A. Dass and M. Raja. 2011. Recent advances in conjugated polymers for light emitting devices. Int. J. Mol. Sci. 12: 2036-2054.

Amato, R. D., I. Fratoddi, A. Cappotto, P. Altamura, M. Delfini, C. Bianchetti, A. Bolasco, G. Polzonetti and M. V. Russo. 2004. Organometallic platinum(II) and palladium(II) polymers ontaining 2,6-diethynyl-4-nitroaniline bridging spacer and related dinuclear model complexes. Organomet. 23: 2860-2869.

Baier, M. C., J. Huber and S. Mecking. 2009. Fluorescent conjugated polymer nanoparticles by polymerization in miniemulsion. J. Am. Chem. Soc. 131: 14267-14273.

Cyr, P. W., E. J. D. Klem, E. H. Sargent and I. Manners. 2005. Photoconductivity in donoracceptor polyferrocenylsilane-fullerene composite films. Chem. Mater. 17: 5770-5773.

Devi, L. S., M. K. A. Suti, N. Zhang, S. J. Teat, L. Male, H. A. Sparkes, P. R. Raithby, M. S. Khan and A. Kohler. 2009. Synthesis and comparison of the optical properties of platinum(II)polyynes with fused and non-fused oligothiophenes. Macromol. 42: 1131-1141.

Hossain, M. I., D. Debnath, M. Younus, M. A. Bari and M. A. J. Miah. 2011. Synthesis and characterization of poly(aryleneethynylene)s and their corresponding platinum-linked polymers. J. Sci. Res. 3: 587-597.

Hattori, T., M. Kijima and H. Shirakawa. 1997. Synthesis of conducting polymers with conjugated carbon-carbon triple bonds by electrochemical condensation of acetylene derivatives atalyzed by copper complex. Synthetic Met. 84: 357.

Kloppenburg, L., D. Jones and U. H. F. Bunz. 1999. High molecular weight poly(pphenyleneethynylene)s by alkyne metathesis utilizing "instant" catalysts: a synthetic study. Macromol. 32: 4194-4203.

Lewis, J., N. J. Long, P. R. Raithby, G. P. Shields, W. Y. Wong and M. Younus. 1997. Synthesis and characterization of new acetylide-functionalised oligothiophenes and their dinuclear platinum complexes. Dalton Trans. 4283-4288.

Long, N. J. and C. K. Williams. 2003. Metal alkynyls complexes: synthesis and materials. Angew. Chem. Int. Ed. 42: 2586-2617. 
Long, N. J., A. J. P. White, D. J. Williams and M. Younus. 2002. Synthesis and characterisation of new platinum ethynyl dimers and polymers with pendant ferrocenyl groups. J. Organomet. Chem. 649: 94-99.

Molapo, K. M., P. M. Ndangili, R. F. Ajayi, G. Mbambisa, S. M. Mailu, N. Njomo, M. Masikini,P. Baker and E. I. Iwuoha. 2012. Electronics of conjugated polymers (I): polyaniline. J.Electrochem. Sci. 7: 11859-11875.

Saha, R., M. A. Qaiunm, D. Debnath, M. Younus, N. Chawdhury, N. Sultana, G. Kociok-Koon, L. Ooi, P. R. Raithby and M. Kijima. 2005. A new series of luminescent phosphine tabilized platinum ethynyl complexes. Dalton Trans. 2760-2765.

Sina, A. A., S. M. I. A. Rafia, M. F. Ahmad, R. K. Paul, S. M. S. Islam, M. Younus, P. R. Raithby, C. L. Ho, Y. H. Lo, L. Liu, H. Li and W. Y. Wong. 2014. Synthesis, structures and properties of novel platinum(II) acetylide complexes and polymers with tri(tolyl)phosphine as the auxiliary ligand. J. Inorg. Organomet. Polym. DOI: 10.1007/s10904-014-0071-7.

Xu, X. D., J. Zhang, X. Yu, L. J. Chen, D. X. Wang, T. Yi, F. Li and H. B. Yang. 2012. Design and preparation of platinum-acetylide organogelators containing ethynyl-pyrene moieties as the main skeleton. Chem. Eur. J. 18: 16000-16013.

Younus, M., A. Köhler, S. Cron, N. Chawdhury, M. R. A. Al-Mandhary, S. K. Muhammad, L. Lewis, N. J. Long, R. H. Friend and P. R. Raithby. 1998. Synthesis, electrochemistry, and spectroscopy of blue platinum(II) poly-ynes and diynes. Angew. Chem. Int. Ed. 110: 32013203. 